\title{
Carbonatites, alkaline rocks and the mantle: a special issue dedicated to Keith Bell
}

\author{
L. G. Gwalani • K. Moore • A. Simonetti
}

Published online: 19 January 2010

(C) Springer-Verlag 2010

This issue of Mineralogy and Petrology on carbonatites, alkaline rocks and the mantle shall intrigue those interested in carbonatite-alkaline complexes and mafic magmatism. The latter association has recently generated much research interest with the investigation of carbonatite/alkaline complexes coeval with volcanism associated with large igneous provinces (LIPs). This volume is published in honour of Prof. Keith Bell, who is recognized as one of the pioneers in using radiogenic isotopes to evaluate the evolution and mantle sources of carbonated and alkaline magmas. The details of his contributions in these areas are summarized by Professor Simonetti in the preface to this volume. While including a few invited papers dealing with

\section{G. Gwalani $(\bowtie)$}

C/O NiPlats Australia Limited,

22/77 Allendale Square, St. Georges Terrace,

Perth, WA 6000, Australia

e-mail: lgwalani@gmail.com

\section{K. Moore}

Department of Earth and Ocean Sciences,

National University of Ireland Galway,

University Road,

Galway, Ireland

e-mail: kathryn.moore@nuigalway.ie

\author{
A. Simonetti \\ Department of Civil Engineering \& Geological Sciences, \\ University of Notre Dame, \\ 156 Fitzpatrick Hall, \\ Notre Dame, IN 46556, USA \\ e-mail: Antonio.Simonetti.3@nd.edu \\ Present Address: \\ L. G. Gwalani \\ C-1, Neel Kamal, 2nd Hasnabad, \\ Santacruz West, Mumbai (Bombay) 400 054, India
}

the petrography, mineral and rock chemistry, and isotopic compositions of flood basalts, this issue of Mineralogy and Petrology also features research contributions akin to the interests of Prof. Bell.

This volume contains 18 contributions of research papers by authors who deal with several important aspects of mantle-related magmatism (carbonatites, alkaline rocks and flood basalts) and mineral deposits associated with carbonatitic magmatism. Several of these papers have been coauthored with people (Bianchini, Ernst, Farrell, Rukhlov, and Simonetti) who were supervised, co-supervised or collaborated with Professor Bell during their graduate/ academic careers.

Of the 527 known carbonatite occurrences world-wide, most have been dated using K-Ar dating and very few have been dated using $\mathrm{U} / \mathrm{Pb}$ zircon geochronology. In spite of the limited age information, previous studies have proposed that carbonatites fall into distinct age groups that may be related to tectonic events of global significance. The paper by Rukhlov and Bell (2009) "Geochronology of carbonatites from the Canadian and Baltic Shields, and the Canadian Cordillera: clues to mantle evolution", reports an impressive number of new, high precision $\mathrm{U} / \mathrm{Pb}, \mathrm{Th} / \mathrm{Pb}$ and $\mathrm{Pb} / \mathrm{Pb}$ dates from 27 intrusive complexes located in Europe and North America. Their age data indicate that some of these events can be correlated with continental fragmentation, mafic magmatism, and plume activity. This impressive new list of ages adds substantially to the geochronological data base for carbonatites.

There is increasing evidence that many carbonatites are linked both spatially and temporally with LIPs made up of flood basalts and their plumbing systems. Examples of LIPcarbonatite associations include: i. the $66 \mathrm{Ma}$ Deccan flood basalt province, ii. the 130 Ma Paraná-Etendeka; iii. the 250 Ma Siberian LIP, iv. the ca. 370 Ma Kola Alkaline 
Province, and v. the 615-555 Ma CIMP (Central Iapetus Magmatic Province) of eastern Laurentia and western Baltica. The paper by Ernst and Bell (2009) "Large Igneous Provinces (LIPS) and carbonatites", provides a detailed summary and discussion of the close spatial and temporal association between carbonatites and LIPs. The authors argue that both flood basalts and their feeder systems along with associated carbonatites are related to plume magmatism, but differ in terms of degree and depth of partial melting, the fluid content of the source, and perhaps even the isotopic composition of the sources associated with plume activity.

The paper by Bell and Simonetti (2009) "Source of parental melts to carbonatites-critical isotopic constraints", deals with the controversial problem of the depth of the mantle source of carbonated melts in continental areas in the light of recent evidence. This paper assesses whether the parental liquids to carbonatites are generated within the continental lithosphere, or whether they are derived from deeper parts of the mantle with the lithosphere playing a subsidiary, but important, role in trapping volatile-rich melts/fluids. Both radiogenic and stable isotope data from world-wide carbonatites, along with recent geophysical information, have been used to convincingly show a sub-lithospheric source for the parental melts, and one that is closely associated with either asthenospheric 'upwellings' or more deep-seated, plume-related activity.

The study by Johnson et al. (2009) "Iron isotope compositions of carbonatites record melt generation, crystallization, and late-stage volatile-transport processes", documents the first $\mathrm{Fe}$ isotope study on carbonatites, including whole-rocks and mineral phases. Their results indicate that carbonatites define the largest range in $\mathrm{Fe}$ isotope compositions yet measured for igneous rocks. The $\mathrm{Fe}$ isotope variations in carbonatites (and associated rockforming minerals) suggest that this relatively new stable isotope system can also provide a tracer of fluid interactions and cooling history. Many of the minerals studied define Fe isotope disequilibrium at igneous temperatures, and this isotopic disequilibrium likely reflects the effects of cooling and fluid/rock interaction. The Fe isotope disequilibrium may also record mixing of phenocrysts from distinct magmas, and therefore provides additional evidence for isotopic disequilibrium in carbonatite magmas, which has been demonstrated in previous stable and radiogenic isotope studies.

The investigation of Bianchini et al. (2009) "Comparative study of ultrafemic xenoliths and associated lavas from South-Eastern Sicily: nature of the lithospheric mantle and insights on magma genesis", re-examines the volcanism associated with the Hyblean region on the basis of a better knowledge of the peridotite and pyroxenite mantle xenoliths exhumed by alkaline lavas, and report new chemical and Sr$\mathrm{Nd}$ isotopic data on mineral phases. The latter obtained from peridotitic clinopyroxenes approach the isotopic composition of the HIMU (mantle reservoir characterized by a timeintegrated high ' $\mu$ value'- high ${ }^{238} \mathrm{U} /{ }^{204} \mathrm{~Pb}$ ) mantle component, recently referred to as the EAR (European Asthenospheric Reservoir). This result emphasizes a connection with a sub-lithospheric metasomatic component ubiquitous throughout Europe, the Mediterranean area and North Africa. The Sr-Nd isotope analyses of the pyroxenites also reveal an EAR affinity, but are slightly different compared to those of the peridotites since they overlap the compositional field defined by the Hyblean alkaline lavas. The $\mathrm{Sr}-\mathrm{Nd}$ isotopic data suggest that the role of the pyroxene-rich portions of the mantle has yet to be properly evaluated in any petrogenetic model for Hyblean magmatism.

The paper "The Yungul carbonatite dykes associated with the epithermal fluorite deposit at Speewah, Kimberley, Australia: Carbon and oxygen isotope constraints on their origin" by Gwalani et al. (2009), describes, in detail, the field relationships, the bulk rock chemistry and $\mathrm{C}$ and $\mathrm{O}$ isotope data of the Yungul carbonatite dykes that intrude the large Paleoproterozoic tholeiitic Hart Dolerite sill and are associated with an economic fluorite deposit. Comparison of the Yungul carbonatite with the one at Amba Dongar, also associated with a fluorite deposit, shows many similarities. The $\mathrm{C}$ isotope data from Yungul indicate that the carbonatites are mantle-derived but have had a complex history involving enrichment in $\delta^{18} \mathrm{O}$, reflecting hydrothermal alteration or crustal contamination, and/or lowtemperature water/rock exchange.

The paper by Comin-Chiaramonti et al. (2009) "Lavas and hosted mantle xenoliths from intracratonic Eastern Paraguay (South America Platform) and Andean Domain: a compressive review" is an extensive assessment that deals with the transitional mantle characteristics from the Andean back-arc region into the intracratonic South American platform in Paraguay, based on mantle xenoliths and host lavas. The comparative study of these mantle xenoliths (spinel-peridotites with compositions varying from lherzolite to dunite) and the host sodic alkaline lavas of Cretaceous to Paleogene age have been described from two distinct tectonic settings: a) a compressive type in the Central Andes and, b) an extensional (rifting) type in the intercratonic region of central eastern Paraguay. On the basis of trace element and radiogenic $(\mathrm{Sr}-\mathrm{Nd}-\mathrm{Pb})$ isotope studies of the lavas and the mantle xenoliths, the authors suggest that irrespective of different tectonic settings, the sodic-alkaline lavas from both regions display very similar geochemical features. The authors show that the geochemical characteristics of mantle xenoliths are similar to most other worldwide, mantle xenoliths hosted in alkali-basalts. 
The contribution of Zhu et al. (2009) "Platinum-group minerals and tellurides from the PGE-bearing Xinjie layered intrusion in the Emeishan Large Igneous Province, SW China", describes the Xinjie layered intrusion of ultramafic to mafic/felsic composition, hosting Fe-Ti-V and $\mathrm{Cu}$-Ni-PGE sulfide deposits, within the Pan-Xi area of the Sichuan Province associated with the Permian plumerelated Emeishan flood basalt province. They report three major PGE-mineralized $\mathrm{Cu}-\mathrm{Ni}$ sulfide layers in the basal part of the Xinjie intrusion. The base-metal sulfides comprise chalcopyrite, pyrrhotite, and pentlandite, which are associated with rare metallic minerals such as sperrylite, moncheite-merenskyite (solid solution), michenerite and Pd-Pt-Bi-Te minerals. On the basis of the textural relationship and mineral-chemistry of the platinum-group minerals (PGM) and base metal sulfide and Fe-Ti oxides (magnetite), the authors suggest that the $\mathrm{Cu}-\mathrm{Ni}$-PGE-bearing layers in the basal part of the intrusion were generated by fractional crystallization. They also suggest that magnetite played an important role in producing a sulfur-saturated melt that created sulfide-silicate liquid immiscibility and that the PGEs were dissolved in the sulfide fraction at high temperatures.

The paper by A. Demény et al. (2009), "Geochemical and $\mathrm{H}-\mathrm{O}-\mathrm{Sr}$-Nd isotope evidence for magmatic processes and meteoric-water interactions in the Basal Complex of La Gomera, Canary Islands", is a comprehensive study of the Basal Complex of La Gomera. Basal complexes of the islands of the Canary archipelago that are comprised of plutonic rocks (predominantly pyroxenites, gabbros and their differentiation products) and basaltic dike swarms, and represent the roots of the volcanic edifices. The authors have used bulk-rock chemistry, and stable and radiogenic isotopic compositions of rocks and minerals within the Basal Complex of La Gomera to assess the primary magmatic compositions related to the upwelling Canary plume along with the effects of late-stage alteration processes and the resulting products. Modeling late-stage alteration due to the influx of meteoric water yielded an estimation of the height of water infiltration. The results of this study are compared with other paleoelevation studies conducted at several islands of the archipelago.

In their paper, "Plume-related mantle source of superlarge rare metal deposits from the Lovozero and Khibina massifs on the Kola Peninsula, Eastern part of Baltic Shield: Sr, Nd and Hf isotope systematics", Kogarko et al. (2009) show that the isotopic ratios, including Hf, of super large rare metal deposits (mainly eudialyte and loparite), hosted by the enormous alkaline intrusions of Lovozero and Khibina, Russia, indicate a closed magmatic system, and generation from an OIB-like mantle source. The isotopic composition of the source is considered to be the Devonian equivalent of FOZO (Focus Zone-unknown, ubiquitous mantle component common in the source region of oceanic island basalts; Hart et al. 1992). The isotope data suggest a deep-seated mantle source for both the alkaline rocks and their associated metals, consistent with plume-related magmatic activity.

The paper, "Sulphur isotopes in carbonatites and associated silicate rocks from the Superior Province, Canada", by Farrell et al. (2009) presents new S isotopic data from sulphide mineral separates as well as C-O isotope ratios from both carbonatites and carbonates in silicate rocks from several carbonatite-alkalic complexes in the Superior Province of the Canadian Shield; these range in age from 1,906 Ma to 1,008 Ma. Each complex seems to have its own limited range of $\mathrm{S}$ isotope compositions. The authors discuss these differences in terms of magmatic evolution, including different modes of emplacement and closed-system fractionation. The variable $\mathrm{S}$ isotope compositions from complex to complex are evaluated in terms of processdriven changes versus heterogeneous mantle sources.

The paper, "Petrogenesis of a basalt-comenditepantellerite suite: the Boseti volcanic complex (Main Ethiopian Rift)" by Ronga et al. (2009) discusses the petrological and geochemical data for a suite of basic and silicic peralkaline rocks from the poorly-known Pleistocene Boseti volcanic complex. They conclude that the silicic rocks were formed as a result of prolonged fractional crystallization of basaltic parent magmas in a nearly-closed system at shallow depths. The associated transitional basalts have the geochemical and isotopic characteristics of the other lavas found throughout the rift floor of Ethiopia. The apparent "Daly Gap" is attributed to silicic magma filling only the shallowest crustal reservoirs, and erupting preferentially in relation to the mafic and intermediate magmas, which flooded the floor of the rift.

In the paper by Doroshkevich et al. (2009a) "Genesis of the Khaluta alkaline-basic Ba-Sr carbonatite complex (West Transbaikala, Russia)", the authors provide a comprehensive interpretation of the mineralogical, geochemical and isotopic data of this extremely interesting complex, emphasizing the important role that liquid immiscibility has played in the genesis of the Khaluta alkaline rocks and carbonatites. The characteristic features of the carbonate-saturated parental melt at Khaluta were elevated concentrations of $\mathrm{SO}_{3}, \mathrm{Ba}$ and $\mathrm{Sr}$ and high oxygen fugacities based on calculated $\mathrm{fO}_{2}$ values for magnetites. These findings suggest that the mantle source for the Khaluta carbonatite and associated rocks, as well as for other carbonatites of the West Transbaikalia carbonatite province, were $\mathrm{SO}_{3}$-rich and characterized by high oxygen fugacities.

The link between mantle plumes and several carbonatite occurrences of India was proposed by Simonetti et al. $(1995,1998)$, and opened up a new direction for evaluating 
the sources of carbonatitic magmatism in the Indian subcontinent. Several manuscripts in this special issue deal with Mg-rich rocks from India and the nature of their mantle sources. Two of these papers deal with Newania, a dolomite-dominated carbonatite complex.

The first of these contributions by Ray et al. (2009) "Carbon and oxygen isotopic compositions of Newania dolomite carbonatites, Rajasthan, India: Implications for source of carbonatites" constitutes an investigation of the stable isotope variations in carbonatites in general and in dolomite carbonatites in particular. Given that dolomite carbonatite magmas are believed to be primary mantle melts this is a particularly important study. In their contribution, the authors have characterized the nature of the mantle source of the Newania carbonatites, and the magmatic and post-magmatic evolution of the complex. Based on their work, they suggest that dolomite carbonatites are derived from mantle sources similar to other types of carbonatites, irrespective of their association with alkaline silicate rocks. They also suggest that $\mathrm{C}$ and $\mathrm{O}$ isotope compositions of carbonatites may have remained relatively unaffected by regional metamorphism.

The second of the contributions on Newania relates to mantle fugacity conditions. In their work on the "Newania carbonatites, western India: example of mantle derived magnesium carbonatites", Doroshkevich et al. (2009b) investigate the mineral chemistry in graphite-bearing magnesite-dolomite carbonatite from Newania, in order to elucidate the fugacity conditions of the mantle. The source region is considered to be fairly oxidized relative to peridotite xenoliths but significantly more reduced than the highly oxidized magmatic rocks of ocean islands and other carbonatite complexes in Greenland, Russia and Canada. The oxygen fugacity range represented by coexisting early-crystallized graphite and magnesite is below that of the FMQ buffer and lies on the CCO buffer.

The paper "Petrogenesis of alkaline rocks from Murud-Janjira in the Deccan Traps, Western India" by Dessai and Viegas (2009) presents new geochemical data on alkaline rocks occurring within the Deccan Trap Province of India. They highlight the complexity of interrelationship between and among the various groups of intrusives and the host basalts. The spatial and temporal compositional diversity and variability within the intrusives and their significance in the tectonomagmatic evolution of this province is discussed. Crustal contamination and magma mixing seem to have played an important role in generating some of the different rock types. This paper contributes to the understanding of magmatic processes in large igneous provinces (LIPs) and provides a provocative base for more detailed research on alkaline intrusive rocks (lamprophyre, nephelinite and tephriphonolite) associated with flood basalts.
The contribution, "Petrology, geochemistry and genesis of new Mesoproterozoic high-magnesian calcite-rich kimberlites of Siddanpalli, Eastern Dharwar Craton, Southern India: Products of subduction-related magmatic sources?" by Chalapathi Rao et al. (2009) uses geochemical methods to investigate kimberlites and the role of mantle cycling in their source region. The mantle plume model that was previously envisaged (Kumar et al. 2007) for producing the Eastern Dharwar Craton (EDC) kimberlite provinces is retained as a potential heat source. However, a subducted lithospheric component has been identified as important in the generation of the Siddanpalli kimberlites. The variations in the EDC kimberlite compositions are related to varying degrees of partial melting and the mixing of fertile, depleted and enriched sources.

The paper by Srivastava et al. (2009), "PGE geochemistry of low-Ti high-Mg siliceous mafic rocks within the Archaean Central Indian Bastar Craton: implications for magma fractionation" reports on the occurrence and platinum group element (PGE) geochemistry of a boninitenorite (BN) suite emplaced within the Archaean central Indian Bastar Craton. The spatial and temporal correlation of these high-Mg, low-Ti siliceous rocks, with similar rocks occurring around the northern Bastar and Dharwar Cratons, are attributed to a remnant Large Igneous Province formed during the Neoarchaean-Paleoproterozoic. PGE and major and certain trace element variations recorded by the $\mathrm{BN}$ suite are consistent with a petrogenetic model involving olivine and chromite fractional crystallization.

It is our sincere hope that this volume will help promote and foster further carbonatite research in general, and investigations into the petrogenetic link between carbonatites and basalt-dominated, large igneous provinces. Several papers in this special issue clearly establish the coeval relationship between carbonatites and flood basalt provinces, and/or their emplacement during periods of major, global tectonism. In such instances, further detailed geochemical, radiogenic and stable isotope investigations are important to help decipher the dynamics of the mantle during melt generation. The important role of convecting mantle in carbonatite melt generation has been clearly demonstrated for East Africa (e.g. Bell and Simonetti 1996; Bell and Tilton 2002); however, the exact chemical nature of the convecting mantle, whether enriched or heterogeneous, is discussed in Bell and Simonetti (this volume). Clearly, there remains much work to be carried out in carbonatite-related research.

Publication of this Special issue would not have been possible without the help of many individuals and the organizations where we work. In particular we wish to thank Stephen Soehnlen (Springer Editor, Physical and Natural Sciences), Prof. J. G. Raith and Prof. R. Abart (Chief Editors, Mineralogy and Petrology), and Silvia 
Schilgerius, Judy Pieren, Edward Sarmiento (Springer Editorial Office). We also wish to thank authors for their contributions. We are indebted to the following individuals (listed in alphabetical order) for reviewing the papers included in this volume:
A. Ahijado
I.A. Andreeva
Yuri Amelin
Dan Barker
Andy Beard
Luigi Beccaluva
Keith Bell
Jose Affonso Brod
Bernhard Buhn
Anton R. Chakmouradian
Ian D. Clark
Piero Comin-Chiaramonti
Ian Coulson
Christian Creixell
Attila Demény
Peter Downes
F. Fareeduddin
Michel Gregoire
Giovanni Grieco
Leo Hartmann
Liya N. Kogarko
Mike J. Le Bas
Leone Melluso
Clive R. Neal
Troels Nielsen
Riccardo Omarini
N.V.Chalapathi Rao
Irene Rass
Jyotiranjan S. Ray
Giorgio Rivalenti
Anders Schersten
Helmut Schliecher
Ronny Schoenberg
A.K. Sen
Sam F. Sethna
H.C. Sheth
Rajesh K. Srivastava
Andreas Stracke
Csaba Szabo
Sebastian Tappe
Ross Taylor
Ilya Veksler
Alan Woolley
Xiao Yong Yang

L.G. Gwalani would like to thank M. Govindram, Jyoti and Shradha Gwalani for the generous help, support and cooperation extended while working on this volume. Keith Bell, David Groves, Ken Rogers, Piero Comin-Chiaramonti, A. Demény, Peter Downes, N.K. Dutta and Dinesh Serai were a constant source of encouragement and help to him (LGG).

\section{References}

Bell K, Simonetti A (1996) Carbonatite magmatism and plume activity: implications from the $\mathrm{Nd}, \mathrm{Pb}$ and $\mathrm{Sr}$ isotope systematics of Oldoinyo Lengai. J Petrol 37:1321-1339

Bell K, Simonetti A (2009) Source of parental melts to carbonatitescritical isotopic constraints. Miner Petrol. doi:10.1007/s00710009-0059-0

Bell K, Tilton GR (2002) Probing the mantle: the story from carbonatites. EOS 83:273, 276, 277

Bianchini G, Yoshikawa M, Sapienza GT (2009) Comparative study of ultramafic xenoliths and associated lavas from South-Eastern Sicily: nature of the lithospheric mantle and insights on magma genesis. Miner Petrol. doi:10.1007/s00710-009-0056-3

Chalapathi Rao NV, Dongre A, Kamde G, Srivastava RK, Sridhar M, Kaminsky FV (2009) Petrology, geochemistry and genesis of newly discovered Mesoproterozoic highly magnesian, calciterich kimberlites from Siddanpalli, Eastern Dharwar Craton, Southern India: products of subduction-related magmatic sources? Miner Petrol. doi:10.1007/s00710-009-0085-y

Comin-Chiaramonti P, Lucassen F, Girardi VAV, De Min A, Gomes CB (2009) Lavas and their mantle xenoliths from intracratonic Eastern Paraguay (South America Platform) and Andean Domain, NW-Argentina: a comparative review. Miner Petrol. doi:10.1007/s00710-009-0061-6

Demény A, Casillas R, Hegner E, Vennemann TW, Nagy G, Sipos P (2009) Geochemical and H-O-Sr-Nd isotope evidence for magmatic processes and meteoric-water interactions in the basal complex of La Gomera, Canary Islands. Miner Petrol. doi:10.1007/s00710-009-0071-4

Dessai AG, Viegas A (2009) Petrogenesis of Alkaline Rocks from Murud-Janjira, in the Deccan Traps, Western India. Miner Petrol. doi:10.1007/s00710-009-0105-y

Doroshkevich AG, Ripp GS, Moore KR (2009a) Genesis of the Khaluta alkaline-basic Ba-Sr carbonatite complex (West Transbaikala, Russia). Miner Petrol. doi:10.1007/s00710-009-0063-4

Doroshkevich AG, Ripp G, Viladkar S (2009b) Newania carbonatites. Western India: example of mantle derived magnesium carbonatites. Miner Petrol. doi:10.1007/s00710-009-0076-Z

Ernst RE, Bell K (2009) Large igneous provinces and carbonatites. Miner Petrol. doi:10.1007/s00710-009-0074-1

Farrell S, Bell K, Clark I (2009) Sulphur isotopes in carbonatites and associated silicate rocks from the Superior province, Canada. Miner Petrol doi:10.1007/s00710-009-0101-2

Gwalani LG, Rogers K, Demény A, Groves DI, Ramsay R, Beard A, Downes PJ, Eves A (2009) The Yungul carbonatite dykes associated with the epithermal fluorite deposit at Speewah, Kimberley, Australia: Carbon and oxygen isotope constraints on their origin. Miner Petrol. doi:10.1007/s00710-009-0102-1

Hart SR, Hauri EH, Oschmann LA, Whitehead JA (1992) Mantle plumes and entrainment: isotopic evidence. Science 256:517-520

Johnson CM, Bell K, Beard BL, Shultis AI (2009) Iron isotope compositions of carbonatites record melt generation, crystallization, and late-stage volatile-transport processes. Miner Petrol. doi:10.1007/s00710-009-0055-4

Kogarko LN, Lahaye Y, Brey GP (2009) Plume-related mantle source of super-large rare metal deposits from the Lovozero and Khibina massifs on the Kola Peninsula, eastern part of Baltic Shield: Sr, 
$\mathrm{Nd}$ and Hf isotope systematics. Miner Petrol. doi:10.1007/ s00710-009-0066-1

Kumar A, Heaman LM, Manikyamba C (2007) Mesoproterozoic kimberlites in south India: a possible link to $1.1 \mathrm{Ga}$ global magmatism. Precambrian Res 15:192-204

Ray JS, Shukla AD, Dewangan LK (2009) Carbon and oxygen isotopic compositions of Newania dolomite carbonatites, Rajasthan, India: implications for source of carbonatites. Miner Petrol. doi:10.1007/s00710-009-0073-2

Ronga F, Lustrino M, Marzoli A, Melluso L (2009) Petrogenesis of a basalt-comendite-pantellerite suite: the Boseti volcanic complex (Main Ethiopian Rift). Miner Petrol. doi:10.1007/s00710-0090064-3

Rukhlov AS, Bell K (2009) Geochronology of carbonatites from the Canadian and Baltic Shields, and the Canadian Cordillera: clues to mantle evolution. Miner Petrol. doi:10.1007/s00710-009$0054-5$
Simonetti A, Bell K, Viladkar SG (1995) Isotopic data from the Amba Dongar carbonatite complex, west-central India: evidence for an enriched mantle source. Chem Geol 122:185-198

Simonetti A, Goldstein SL, Schmidberger SS, Viladkar SG (1998) Geochemical and $\mathrm{Nd}, \mathrm{Pb}$, and $\mathrm{Sr}$ isotope data from Deccan alkaline complexes-inferences for mantle sources and plumelithosphere interaction. J Petrol 39:1847-1864

Srivastava RK, Mondal SK, Balaram V, Gautam GC (2009) PGE geochemistry of low-Ti, high-Mg siliceous mafic rocks within the Archaean Central Indian Bastar Craton: implications for magma fractionation. Miner Petrol. doi:10.1007/s00710-0090103-0

Zhu W-G, Zhong H, Hu R-Z, Liu B-G, He D-F, Song X-Y, Deng H-L (2009) Platinum-group minerals and tellurides from the PGEbearing Xinjie layered intrusion in the Emeishan Large Igneous Province, SW China. Miner Petrol. doi:10.1007/s00710-0090077-y 